\title{
E-Muhasebe Uygulamaları Kapsamında Güncel Sorunlar ve Çözüm Önerileri: Karaman'da Bir Araştırma
}

\section{Current Issues and Solutions in E-accounting Practices: A Research in Karaman}

\author{
Fehmi KARASIOĞLU* \\ Okan GARIP**
}

\begin{abstract}
$\ddot{O} Z$
Bilgi teknolojilerinde yaşanan gelişmeler hayatın her alanını etkilediği gibi muhasebe alanında da kendini göstermiştir. Muhasebede E-uygulamaların kullanılmaya başlanması ise bilgi teknolojilerinin getirdiği en son yeniliklerden olmuştur. Hazine ve Maliye Bakanlığı kayıt dışı ekonomiyi tespit edebilmek, vergi kaybını önleyerek vergi gelirlerinin arttırabilmek, denetimi hızlandırabilmek, bilgiye erişimi kolaylaştırabilmek gibi amaçlar ile muhasebede e-dönüşüm sürecini başlatmıştır. Bu dönüşümün hem kamu hem de özel sektöre sağlayacağl avantajlar göz ardı edilemez. Ancak bu avantajların yanında uygulamada çeşitli sorunlarında yaşanabilmesi mümkündür. Bundan dolayı bu çalışmada, euygulamaların en aktif kullanıcıları olan muhasebe meslek mensuplarının e-dönüşüm sürecinde yaşadıkları sorunların tespit edilmesi ve bu sorunlara çözüm önerilerinin getirilebilmesi amaçlanmıştır. Bu amaçla, Karaman Serbest Muhasebeci Mali Müşavirler Odasına üye meslek mensuplarının 138'i ile anket çalışması yapılmıştır. Yapılan analiz sonucunda e-dönüşüm konusunda kalifiye eleman eksikliği en çok sorun olarak algılanan konu olmuştur. Bu nedenle başta Hazine ve Maliye Bakanlığı ve meslek odaları olmak üzere verilen eğitimlerin periyodik olarak tekrarlamasını sağlamalıdırlar. Düzenlenen eğitim, seminer ve panellerden sadece Serbest Muhasebeci Mali Müşavirler değil euygulamalarını gönüllü veya zorunlu olarak kullanan mükelleflerin de faydalanmasını sağlamak yararlı olabilir.
\end{abstract}

\section{ANAHTAR KELIMELER}

E-Dönüşüm, E-Dönüşüm Uygulamaları, E-Dönüşümde Yaşanan Sorunlar, Muhasebe Meslek Mensuplarl, Karaman

\begin{abstract}
Developments in information technologies have influenced not only every fields of life but also accounting practices. The introduction of e-applications in accounting is one of the latest innovations brought by information technologies. The Ministry of Treasury and Finance of the Republic of Turkey initiated the e-transformation process in accounting with the purpose of identifying the informal economy, preventing tax losses to increase tax revenues, accelerating tax auditing processes and facilitating access to information. The benefits of this transformation to both public and private sectors cannot be denied. Despite these benefits, there are particular issues in practice to fully benefit from e-transformation. Therefore, the aim of this study is to determine issues experienced by professional accountants being the most active users of e-applications in the e-transformation process and also to identify solutions to these issues. For this purpose, a questionnaire was carried out with 138 of the registered members of the Karaman Association of Certified Public Accountants. The main finding is that lack of qualification of currently employed personnel in e-transformation has been the most reported issue. For this reason, it is widely believed that especially the Ministry of Treasury and Finance and professional associations should provide constant and relevant e-transformation related trainings. It may be beneficial to enable not only independent accountants and financial advisors but also the taxpayers involved in voluntary or compulsory e-applications to benefit from the e-transformation related trainings, seminars and panels.
\end{abstract}

\section{KEYWORDS}

E-Transformation, E-Transformation Practices, E-Transformation Problems, Accounting Professionals, Karaman

\begin{tabular}{|c|c|c|}
\hline \multicolumn{2}{|c|}{$\begin{array}{c}\text { Makale Geliş Tarihi/Submission Date } \\
15.03 .2019\end{array}$} & \multicolumn{1}{c|}{$\begin{array}{c}\text { Makale Kabul Tarihi / Date of Acceptance } \\
21.05 .2019\end{array}$} \\
\hline \multirow{3}{*}{ Atıf } & $\begin{array}{l}\text { Karasioğlu, F. ve Garip, O. (2019). E-Muhasebe Uygulamaları Kapsamında Güncel Sorunlar ve Çözüm Önerileri: } \\
\text { Karaman'da Bir Araştırma. Selçuk Universitesi Sosyal Bilimler Meslek Yüksekokulu Dergisi, 22 (2), 433-446. }\end{array}$ \\
\hline
\end{tabular}

\footnotetext{
* Prof. Dr., Selçuk Üniversitesi, İktisadi ve İdari Bilimler Fakültesi, İşletme Bölümü, fehmibey@ gmail.com, ORCID: 0000-0001-6940-3033

** Öğr.Gör., Karamanoğlu Mehmetbey Üniversitesi, Sosyal Bilimler MYO,Finans Bankacılık ve Sigortacılık Bölümü, okangarip@kmu.edu.tr, ORCID:0000-0002-8062-6024
} 


\section{GİRIŞ}

Teknoloji dünyasında yaşanan gelişmeler ve yenilikler hayatın her alanında kendini göstermektedir. Bu gelişmelerin başında ise muhasebe uygulamalarında elektronik dönüşüm olduğu söylenebilir. Ülkemizde edevlet projesi ile elektronik ortama geçiş süreci hayata geçirilmiştir. Muhasebe de ise bu dönüşüm, faturaların elektronik ortamda oluşturulması ve defterlerin elektronik olarak tutulması ile başlatılmıştır.

Ülkemizde elektronik dönüşüm süreci birçok ülkeden çok daha önce başlatılmıştır. Muhasebede elektronik dönüşümün sağlanabilmesi için ülkemizde Hazine ve Maliye Bakanlığı yetkilendirilmiştir. Bu bağlamda ilk olarak e-fatura uygulaması ile başlayan süreç belirli kriterlere göre kullanım zorunluluğu getirilerek uygulamaya sokulmuştur. Daha sonra bu uygulamaların kapsamı genişletilmiştir. Kayıt dışı ekonomiyi tespit edebilmek, vergi kaçağını engelleyebilmek, denetimi hızlı ve kaliteli olarak yapabilmek, bilgiye erişimi kolaylaştırmak, maliyet tasarrufu sağlayabilmek gibi amaçlar ile bu uygulamaların kapsama alanı genişletilerek devam edeceği öngörülebilir.

Vergi kanunlarına uyumun arttırılması, kayıt dışılığının önlenebilmesi gibi nedenlerle başlatılan muhasebede e-dönüşüm ile E-Fatura, E-Defter, E-Arşiv gibi uygulamalar kullanıma girmiştir. Bu amaçla çalışmada ilk olarak muhasebede e-dönüşüm süreci ve uygulamaları ayrıntılı olarak açıklanmıştır. Son olarak uygulama kısmında ise, Karaman da faaliyet gösteren Serbest Muhasebeci Mali Müşavirler (SMMM) üzerinde, e-muhasebe uygulamaları kapsamında güncel sorunlar ve çözüm yolları belirlenmesi amacıyla yapılan anket çalışmasına ait bulgular değerlendirilmiştir.

\section{MUHASEBEDE E-DÖNÜŞÜM VE UYGULAMALARI}

Bilgi iletişim teknolojilerinde yaşanan hızlı değişim ve gelişim sosyo-ekonomik birçok alanı etkilemiştir (Gönen ve Solak, 2017:64). İ̧̧letmelerin faaliyet ve iş hacimleri büyüdükçe işletme çevresini oluşturan çikar gruplarının bilgi ihtiyaçları da artmıştır (Karasioğlu ve Samancı, 2018). Bu gelişmeler sayesinde muhasebe alanın da bilgisayar kullanımının artması borç alacak takibi, maaşların hesaplanması, faturalama, stok takibi ve müşteri kayıtları gibi faaliyetlerin aynı anda ve çok daha kolay bir şekilde yapılabilmesine olanak tanımıştır (Güney, 2014:854). Yaşanan tüm bu gelişmelerin bir sonucu olarak ülkemizde e-Devlet uygulamaları kapsamında e-dönüşüm süreci başlamıştır. E-dönüşümün etkilerinin muhasebe uygulamalarına da yansıdığ1 görülebilmektedir (Gönen ve Solak, 2017:64).

Vergi Usul Kanunu (VUK) ve Türk Ticaret Kanunu (TTK) kapsamında yapılan düzenlemeler ve ikincil mevzuatta yapılan değişiklikler ile ülkemizde muhasebenin e-dönüşüm süreci başlamıştır. Buna göre elektronik olarak defterlerin, kayitların ve belgelerin oluşturulabilmesi, kaydedilip, iletilebilmesi, muhafazasının sağlanması ve gerektiğinde ibrazının yapılabilmesi ile defter ve belgelerin elektronik olarak tutulması ile ilgili tüm hususları düzenlemeye yetkili kurum Hazine ve Maliye Bakanlığı olarak belirlenmiştir (Tektüfekçi, 2013: 90). Buna göre, Hazine ve Maliye Bakanlığı tarafından e-dönüşüm konusunda, belli şartlar altında ilk olarak e-fatura uygulamasının kullanımı zorunlu hale getirilmiştir. VUK genel tebliğleri ile uygulamanın sınırları çizilerek kullanım şartları belirlemiştir (Yürekli, ve diğ., 2016:293).

Klasik muhasebede belge, işlem sürecinin başlangıcı iken elektronik muhasebede belge işlemin bir sonucu olarak karşımıza çıkmaktadır. Elektronik evrakların birçok özelliği bulunmaktadır. Ancak kullanım amacı ve rolü olarak kağıt evrak ile aynı hukuki niteliğe sahiptir. Muhasebe belgeleri ister kağıt ortamında isterse de elektronik ortamda üretilsin mali nitelikli kanıtlayıcı bir belge olma özelliğe sahiptir (Yürekli, ve diğ., 2016:291). E-dönüşüm, yeni bir muhasebe sistemi ortaya koymak yerine mevcut sistemin elektronik ortama aktarılması şeklinde gerçekleşmiştir (Güney ve Özyiğit, 2015:290).

\subsection{E-Muhasebe Uygulamalarına Geçiş Gerekçeleri}

Muhasebenin elektronik ortama aktarılmasının temel gerekçesi, ülkemizin ulusal ve uluslararası standartlara uyum sürecinde uygun alt yapısının oluşturulmasını sağlamaktır. Bir diğer amaç ise vergiye gönüllü uyumun arttırılabilmesidir. Bu bağlamda yapılan çalışmalar ile mükelleflerin vergi kanunlarına uyumlarının arttırılması ve kayıt dışı ekonominin izlenerek önlenebilmesi gayesiyle, e-fatura ve e-defter tutulmas1 zorunlu hale getirilmiştir (Tektüfekçi, 2013:90-91). Tüm bu uygulamalar mükellefler aras1 hizmetlerin etkinleştirilmesi, işlemlerin hızlandırılması, belgelerin muhafazasını kolaylaştırması, vergi incelemesinde etkinliğin arttırılması ve ekonomide kayıt dışılığın önüne geçilmesi ana hedeflerinin yanında işletmelerin maliyetlerini azaltmak, stok kontrolünü ve üretim süreci hakimiyetinin arttırılmasını sağlamak gibi yardımcı hedefleri de bulunmaktadır (Demirkan, 2013:70).

E-uygulamalar ile işletmeler birçok önemli avantaj sağlamaktadır. Bunlar; fatura düzenleme ve gönderme, fatura kabul gibi işlemlerin düşük maliyetli olarak yapılabilmesine, idari hataların en aza indirilmesine, her yıl milyonlarca kağıt faturadan tasarruf edilmesine imkan verebilmektedir. (Ortega, 2012). Ayrıca bu 
avantajlara ilave olarak arşivleme için yer ayrılmasına gerek kalmaması, iç kontrol ve dış denetimin kolay bir şekilde ve hızlı olarak yapılabilmesi, belge düzenlemede oluşacak hataların önlenmesi, ödeme sürelerinin kısalması, ihtiyaç anında eski belgelere anında ulaşılmasına imkan sağlayabilmesi gibi olanaklar sunmaktadır (Yanık ve Karadaş, 2013:136).

\subsection{Elektronik Ortamdaki Muhasebe Kayıt Araçları}

Vergi kanunlarına uyumun arttırılması ve kayıt dışı1ığının önlenmesi için başlatılan e-dönüşüm sürecinde önemli gelişmeler yaşanmıştır. Bu bağlamda getirilen yeni uygulamalar olarak E-Fatura, E-Defter, E-Arşiv bu bölüm altında incelenecektir.

\subsubsection{E-Fatura}

E-Fatura, VUK ve TTK' ya göre, zorunlu olarak tutulmas1 gereken faturaların, elektronik ortamda oluşturulup kaydedilip, arşivlenmesine ve gerektiğinde sunulabilmesine olanak sağlayan bir sistemdir (Kara ve Y1lmaz, 2017:229).

E-Fatura, ülkemizde VUK 397 sıra no.lu tebliği ile muhasebe hayatına girmiş ve 05.03.2010 tarihi itibariyle de uygulamaya başlanmıştır. VUK göre bir faturada olması gereken tüm bilgilerin yer aldığı, iletişiminin merkezi bir platform aracilığıly gerçekleştirildiği elektronik bir belge türüdür. (www.efatura.gov.tr, Erişim Tarihi: 02.01.2019). E- fatura, geleneksel kağıt faturalar ile karşılaştırıldığında işlemlerin çok daha şeffaf olarak yerine getirilebilmesine yardımcı olmaktadır (Lian, 2015:100).

E-fatura uygulamasını kullanmak isteyen vergi mükellefleri, yalnızca e-fatura sisteminde kayıtlı olan mükelleflere fatura düzenleyebilmektedirler. E-fatura almak isteyen mükelleflerinde aynı şekilde Gelir İdaresi Başkanlığı (GïB) tarafından sağlanan uygulama üzerinden fatura düzenleyen mükelleflerden fatura alabilmektedirler. Dolayısıyla, e-fatura düzenlemek veya e-fatura almak isteyen mükelleflerin her ikisinin de GIBB sisteminde kayıtlı e-fatura kullanıcısı olma zorunlulukları bulunmaktadır (Kara ve Y1lmaz, 2017: 229).

\subsubsection{E-Fatura Kullanma Zorunluluğu Olan Mükellefler}

VUK 421 sıra numaralı Genel Tebliği’ne göre;

- “04.12.2003 tarihli ve 5015 sayılı Petrol Piyasası Kanunu kapsamında madeni yağ lisansına sahip olanlar ile bunlardan 2011 takvim y1lında mal alan mükelleflerden 31.12.2011 tarihi itibariyle asgari 25 Milyon TL brüt satış hasılatına sahip olanlar" ile,

- “06.06.2002 tarihli ve 4760 sayılı Özel Tüketim Vergisi Kanunu’na ekli (III) sayılı listedeki malları imal, inşa veya ithal edenler ile bunlardan 2011 takvim yılında mal alan mükelleflerden 31.12.2011 tarihi itibariyle asgari 10 Milyon TL brüt satış hasılatına sahip olanlara,"

e- defter tutma ve e-fatura uygulamasına dahil olma zorunluluğu getirilmiştir.

\subsubsection{E-Fatura Uygulama Süreci}

E-faturadan faydalanan kullanıcılar, sistemde kayıtlı olan kullanıcılara e-fatura gönderebilecek, bu faturaları bilgisayarlarına indirebilecek, istenildiği an ibraz edebileceklerdir (Demirkan, 2013:70). E-faturanın başvuru aşamasında mükellefin öncelikle mali mühür veya e-imzayı temin etmiş olmalıdırlar. Mali mühür veya e-imzaya temin eden işletmeler e-fatura başvuru işlemini yapmalarının ardından GỉB'in uygun görmesi halinde e-fatura uygulamasını kullanabilmektedirler. İşletmelere e-faturadan yararlanabilmeleri için GỉB portalı, entegrasyon yöntemi veya özel entegrasyon yöntemi olmak üzere üç seçenek sunulmuştur. (Gökçen ve Özdemir, 2016:145).

E-fatura uygulamasının üç tarafı bulunmaktadır. Bunlar gönderici birimi, merkez ve alıcı birimden oluşur. Göndericinin posta kutusuna alıcının göndermek istediği bir fatura, merkezi bir platform üzerinden gönderilmektedir. E-fatura, kapalı bir ağ şeklinde tasarlanarak oluşturulmuştur. E-fatura uygulaması, merkez tarafından tanımlanacak gönderici birim ve posta kutusu yazılımları ile çalışmakta ve aşağıdaki diyagramda da görülebildiği gibi gönderici birim ve posta kutusu arasında faturalaşma merkez üzerinden sağlanmaktadır (Yürekli, ve diğ., 2016:295). 


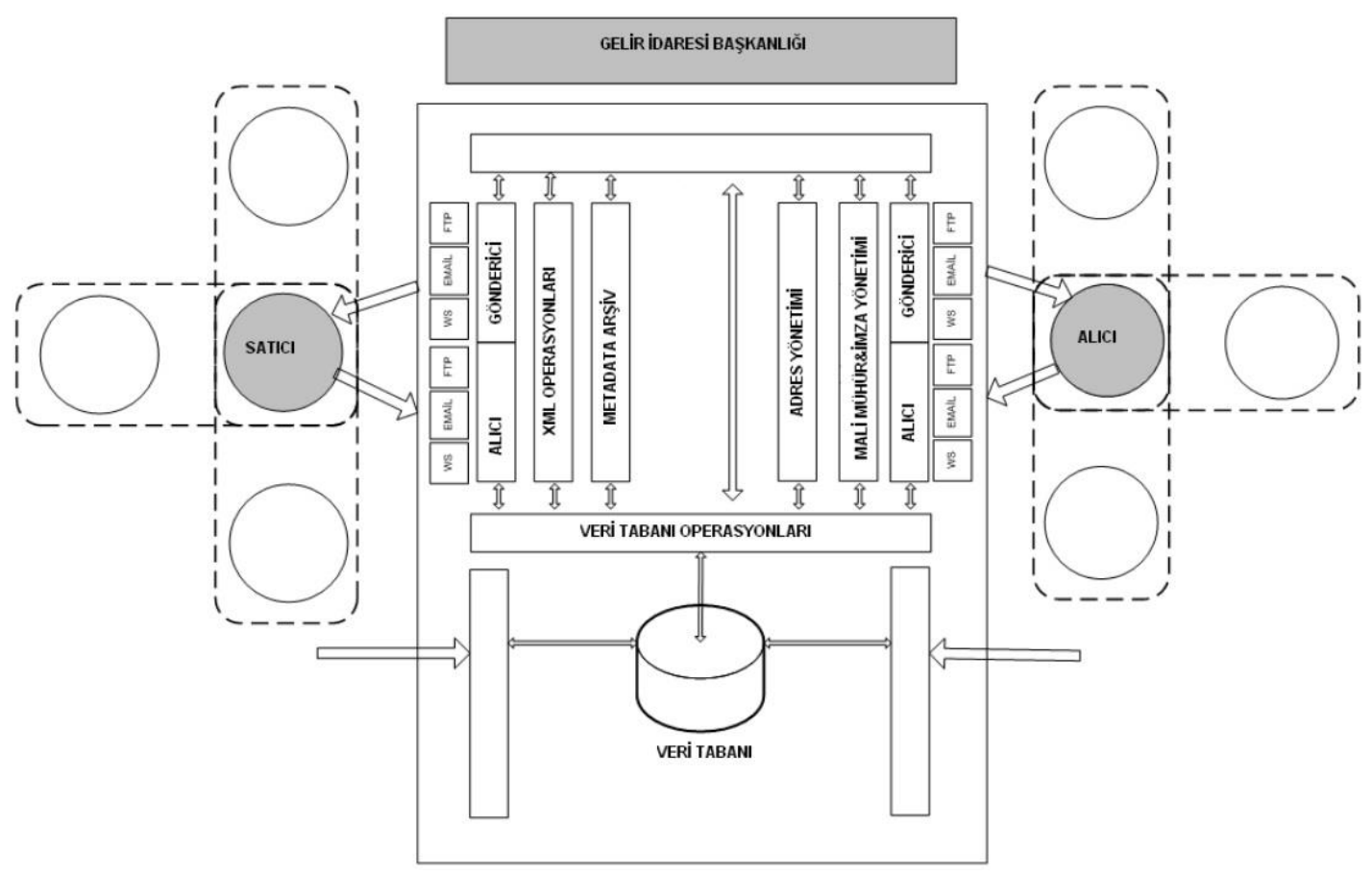

Şekil 1: E-Fatura Uygulaması (www.efatura.gov.tr, Erişim Tarihi: 02.01.2019)

\subsubsection{E-Defter}

1 Sıra Nolu Elektronik Defter Genel Tebliği’ne göre, “Elektronik defter şekil hükümlerinden bağımsız olarak Vergi Usul Kanunu'na ve/veya Türk Ticaret Kanunu'na göre tutulması zorunlu olan defterde yer alması gereken bilgileri kapsayan elektronik kayıtlar bütünü” şeklinde tanımlanmıştır (E-Defter Genel Tebliği, 2011). E-defter, VUK ve TTK'ya göre kağıt ortamında tutulması gereken defterler ile aynı hukuki niteliğe sahiptir (Calayoğlu, 2019:153). Başka bir ifade ile e-defter, tutulması zorunlu olan defterlerin, elektronik dosya olarak hazırlandığı, kağıt olarak bastırılmadan kaydedildiği, değişmezliğinin, bütünlüğünün ve kaynağının doğruluğunun mali mühür veya elektronik imza ile sağlandığı düzenlemeler bütünüdür (Doğan ve Tercan, 2015).

E-defter, defterlerin kâğıt ortamında düzenlenmesi zorunluluğunu ortadan kaldıran ve dolayısıyla da mükellefleri kâğıda basma, onaylatma ve arşivleme gibi yüklerden kurtaran bir e-uygulamadır. Ayrıca denetleme ve raporlamanın standart olacak bir veri halinde tutulmasına imkan sağlaması nedeniyle kendisinden beklenen fayda önümüzdeki dönemlerde daha iyi anlaşılacaktır (Doğan ve Tercan, 2015).

E-defterin kullanabilmek için Extensible Markup Language - Genişletilebilir İşaretleme Dili (XML) formatında bir standart olan ve uluslararası kullanıma sahip Extensible Business Reporting LanguageGenişletilebilir İşletme Raporlama Dili (XBRL) esas alınarak hazırlanması gerekmektedir (Kara ve Yılmaz, 2017: 225).

Elektronik defter tutmak isteyen mükellef gerçek kişi olması durumunda Elektronik İmza Kanunu hükümleri çerçevesinde üretilen NES veya Mali Mühür, tüzel kişi ise Mali Mühür temin etmiş olması ve bunlar için uyumluluk onayı almış bir yazılım kullanması gerekmektedir. Bu kapsamda Türkiye'de e-defter uygulamasına geçen şirket Axa Sigorta A.Ş. ilk üretim işletmesi ise Şölen olduğu bilinmektedir (Tektüfekçi, 2017:83).

E-defter uygulaması için daha önce 421 Sira No.lu VUK. Genel Tebliğinde belirlenen hususlara ilave olarak 20.06.2015 tarihli ve 29392 Sayı1ı Resmi Gazete de yayınlanan 454 Sira No.lu VUK Genel Tebliği ile e-defter uygulamasının kapsamı genişletilmiştir. Bu tebliğe göre aşağıda belirtilen mükellef grupları da e-defter uygulamasına geçmeleri zorunlu hale gelmiştir (VUKGT, Sıra No: 454).

- "2014 veya müteakip hesap dönemleri brüt satış hâsılat1 10 Milyon TL ve üzeri olan mükellefler,

- 4760 Sayılı Özel Tüketim Vergisi Kanununa ekli I Sayılı listedeki malların imali, ithali, teslimi vb. faaliyetleri nedeniyle Enerji Piyasası Düzenleme Kurumundan lisans alan mükellefler,

- Özel Tüketim Vergisi Kanununa ekli III sayılı listedeki malları imal, inşa ve ithal eden mükellefler." 
Bugün itibariyle e-defter uygulamasını kullanan mükellef sayıs1 86.716 adettir (http://www.edefter.gov.tr, Erişim Tarihi 03.02.2019).

\subsubsection{E-Arşiv}

İşletmelerin ticari nitelikli işlemleri nedeniyle her alış ve satı̧ işlemleri esnasında fatura düzenlemeleri gerekmektedir. Bazı sektörlerde iş hacminin nispeten yüksek olması nedeniyle alış ve satış faturaları sayısını bir hayli arttırmaktadır. Bu yüzlerce faturanın kanuni süreler içerisinde arşivlenmesi ve saklanması esnasında zorluklar yaşanabilmektedir. Bu noktada e-arşiv işletmelerin bu zorlukları aşabilmesi için büyük kolaylıklar sağlayan bir uygulama olarak kullanılmaktadır (Elçin, ve diğ., 2018:19).

433 Seri Nolu Vergi Usul Kanunu Genel Tebliği ile yürürlüğe giren e-Arşiv Uygulaması, GİB tarafından belirlenen standartlara uygun olarak faturanın elektronik ortamda oluşturulması, elektronik ortamda muhafazası, ibrazı ve raporlamasını kapsayan bir uygulamadır. E-Arşiv uygulamasından yararlanmak isteyen mükelleflerin, öncelikle e-fatura uygulamasına kayıtlı olmaları gerekmektedir. İnternet üzerinden mal ve hizmet satışı yapan ve 2014 yılı gelir tablosu brüt satış hasılatı tutarı 5 milyon lira ve üzerinde olan mükellefler, en geç 1/1/2016 tarihine kadar e-Arşiv uygulamasına geçmek zorundadırlar (http://www.efatura.gov.tr, Erişim Tarihi:12.02.2019).

\subsection{E-Muhasebede Güncel Sorunlar}

E-fatura ve e-defter gibi muhasebe uygulamaları kullanan mükellef sayısı her geçen gün artmakta ve yapılan mevzuat düzenlemeleri ile de kapsamı genişletilmektedir. Binlerce mükellef tarafindan kullanılan uygulamalar olması nedeniyle bazı belirsizlikler ve sorunları da beraberinde getirmektedir. E-uygulamaların mükellefler tarafından kullanımı karşısında oluşabilecek sorunlar genel olarak kalifiye eleman eksikliği, teknolojik alt yapılarının yetersizliği veya kullanılan programların e-uygulamalara entegre edilmesinin maliyetli görülmesi, uygulamalar konusunda verilen eğitimlerin yetersiz kalabilmesi, kullanılan sistemlerden kaynaklı teknik problemlerin yaşanabilmesi birer örnek olarak karşımıza çıkmaktadır.

Elektronik olarak düzenlenmesi gereken fatura ve defterler klasik yöntemle tutulması durumunda fatura ve defterin hiç tutulmamış sayıldığı bilinmektedir. Fatura almama veya vermeme, defterlerini ibraz edememe nedeniyle özel usulsüzlük cezaları uygulanabilmektedir. Aynı zamanda defterlerinin yazılmaması sebebiyle katma değer vergisi indirimlerinin reddedilmesi ayrı ayrı sorunlar olarak mükelleflerin karşısına çıkan sorunlardır. Gelir İdaresi Başkanlığı (GİB), bu konuda oluşabilecek sorunları engellemek adına esneklik göstererek çözüm üretmeye çalışmıştır. Örneğin bugünkü tarihte hazırlanan önceki tarihli bir fatura e-fatura olarak düzenlenip muhatabına gönderilmektedir. Kağıt olarak hazırlanan faturanın ise iptali yapılmaktadır (www.istanbulymmo.org.tr, Erişim Tarihi:12.02.2019).

\section{LITERATÜR}

Muhasebede elektronik dönüşüm ve uygulamaları konusunda ulusal ve uluslar arası yapılan belli başlı çalışmalara ait bulgular aşağıda yer almaktadır.

Dinç ve Karakaya (2004) yaptıkları çalışma ile, muhasebe meslek elemanlarının e-muhasebe uygulamaları konudaki bilgi düzeyini ölçülmeye çalışmışlardır. Bu amaçla Doğu Karadeniz Bölgesinde faaliyet gösteren 376 meslek elemanı üzerinde anket çalışması gerçekleştirilmiştir. Anket sonuçlarına göre genç meslek elemanlarının e uygulamaları kullanım oranının daha yüksek olduğu, cinsiyet açısından ise bir farklılığın görülmediği anlaşılmıştır. Son olarak ise, yeterli alt yapının oluşturulması, meslek elemanlarına eğitim verilmesi ve internet güvenliğinin arttırılması için gerekli çalışmaların yapılması önerilmiştir.

Çınar ve Güney (2012) yaptıkları çalışmada, serbest muhasebeci mali müşavirlerin (SMMM) euygulamaları kullanımları sırasında yaşadıkları sorunların tespit edilmesi amaçlanmıştır. $\mathrm{Bu}$ amaçla Erzurum'da faaliyet gösteren 105 SMMM üzerinde araştırma yapılmıştır. Araştırma bulgularına göre, bilişim alt yapılarında eksikliklerin olduğu ve mevzuat değişikliklerinin zamanında sisteme uyarlanamadığı, meslek mensuplarının muhasebe yazılımlarının yetersiz olduğunu tespit etmişlerdir. Ayrıca meslek adaylarına yeterli eğitim verilmesi gerektiğine dikkat çekmişlerdir.

Amudi ve diğ. (2012), Gana'daki Küçük ve Orta Ölçekli İşletmeler (KOBİ) arasındaki e-muhasebe uygulamaları incelenmiştir. KOBİ'ler, muhasebe yazılımlarını ve e uygulamaları kullanabilmek için kendi bünyelerinde muhasebe meslek mensubu çalıştırdığı tespit edilmiştir. KOBİlerin çoğunlukla finansal bilgi üretebilmek için e-uygulamaları kullandıkları anlaşılmıştır. Ayrıca işletmelere maliyet düşürme, verileri saklama, yönetim kararlarının alınmasına yardımcı olma gibi avantajlarının bulunduğunu ortaya koyulmuştur.

Öz ve Bozdoğan (2012) yaptıkları çalışmada, Türkiye'deki e-muhasebe uygulamaları mevzuat bazında ele alınmıştır. Çalışma ile ilgili mevzuatta yer alan eksikliklerin tespit edilmesi ve çözüm önerileri getirmesi 
amaçlanmıştır. E-uygulamalar konusunda mevzuat alt yapısının yetersiz kaldığı ortaya koyulmuştur. Tüm mükelleflerin e-uygulamaları kullanmasının faydalı olabileceği vurgulanmıştır.

Tektüfekçi (2013), elektronik ortamda gerçekleştirilen muhasebe uygulamalarını çalışma konusu yapmıştır. E uygulamalara geçişlerin artması ile basım ve toner, defterlerin ciltletilmesi, noter tasdiki ve arşivleme, muhasebe çalı̧̧anlarının zaman ve işgücü gibi maliyetlerinde önemli tasarrufların sağlanabileceği vurgulanmıştır. Ayrıca e-uygulamalar ile hızlı ve güvenli veri erişimi, standart, anlaşılabilir, karşılaştırılabilir rapor üretimi sağlanabileceğini söylemektedir.

Spoz (2014) çalışmasında, Polonya'da faaliyet gösteren işletmelerin e-fatura uygulamaları sırasında karşılaşılan sorunlara değinilmiştir. Dünyada ve Avrupa da e-dönüşüm konusunda gittikçe yaygınlaştığını ancak Polonya'da istenilen düzeyle olmadığı söylenmiştir. Bunu nedeni olarak ise, istikrarsızlık, yasal düzenlemelerin yetersizliği, e-uygulamalar konusundaki bilgi eksikliği, internet alt yapısının yetersiz kalması gibi nedenler gösterilmiștir.

Lian (2015), Tayvan'da yeni bir uygulama olarak kullanılmaya başlanan e-fatura uygulamasının anlaşılabilmesi için ampirik bir çalışma gerçekleştirmiştir. 251 adet geçerli anket ile yapılan çalışmanın sonuçlarına göre, e-uygulamalar konusunda algılanan risk düzeyi ve duyulan güven arasında cinsiyetin, sosyal etkinin ve davranışsal niyetin karar vermede belirleyici olduğu sonucuna ulaşmışlardır.

Marinagi ve diğ. (2015), elektronik faturanın Yunanistan'da kullanımını incelemek amaciyla bir alan araştırması yapmışlardır. 42 işletmeden elde edilen anket verilerine göre, Yunanistan'da e-uygulamaları kullanım oranının düşük olmasına rağmen kabul edilmesinin umut verici olduğu vurgulanmıştır. Çalışmada özellikle e-fatura kullanımını engelleyen faktörlerin üzerinde durulmuştur. Buna göre bilgi birikiminin yetersiz kalması ve yönetim desteğinin olmaması iki ana sorun olarak gösterilmiştir.

Yürekli ve diğ. (2016), çalışmalarında, derinlemesine görüşme tekniği ile elde ettiği verileri analiz etmişlerdir. Elde etmiş oldukları sonuçlara göre, muhasebe meslek mensuplarının e-fatura uygulamalarını olumlu bir gelişme olarak karşıladıkları, işlemlerin hızlı ve güvenli olarak yapılabilmesine, denetimin daha şeffaf olarak gerçekleştirilebilmesine ve veri aktarımının sağlıklı yapılabilmesi imkan verdiği görüşünde birleşildiği anlaşılmıştır. Bunun yanında aşılması gereken sistemsel sorunların varlığı da görüş birliğine varılan bir diğer konu olmuştur.

Gönen ve Solak (2017) tarafından yapılan çalışmada, e-dönüşüm sürecine ilişkin, iş yükü, hizmet maliyeti gibi konularda muhasebe elemanlarının bakış açılarının tespit edilebilmesi amaçlanmıştır. $\mathrm{Bu}$ amaç doğrultusunda e-uygulamaları aktif olarak kullanan ve İzmir'de faaliyet gösteren ve meslek mensupları ile anket çalışması yapılmıştır. Sonuç olarak meslek mensuplarının e-uygulamalarda sistemsel hatalar yaşadıkları ve ek maliyetlere katlanmaları gerektiği tespit edilmiştir.

Elçin ve diğ. (2018) tarafından gerçekleştirilen çalışmada, e-fatura, e-defter ve e-arşiv uygulamalarına geçiş sürecinde yaşanan sorunların tespit edilmesi amaçlanmıştır. E-uygulamaları aktif şekilde kullanmaları nedeniyle 389 Serbest Muhasebeci Mali Müşavir üzerinde anket çalışması yapılmıştır. Çalışmaya göre, iş yükü, sistemsel eksiklikler, alt yapı ve teknik personel eksikliği sorunlarının olduğu tespit edilmiştir.

\section{UYGULAMA}

\subsection{Araştırmanın Metodolojisi}

Çalışmanın amacı, evreni, örneklemi, sınırlılıkları, yöntemi, kullanılan teknikler ve bulgular bu kısımda açıklanacaktır.

\subsection{Araştırmanın Amacı}

Bu çalışmanın temele amacı, muhasebe meslek mensuplarının e-dönüşüm sürecinde yaşamış oldukları sorunların tespit edebilmek ve çözüm önerileri getirebilmektir. Bilgi teknolojilerinin getirdiği yeniliklerden olan e-uygulamaların en aktif kullanıcıları olarak muhasebe meslek mensuplarının gözünden yaşanan eksiklik ve sorunları tespit edilebilmesi ve değerlendirilebilmesi önem arz etmektedir. Bu amaçla Karaman Serbest Muhasebeci Mali Müşavirler Odasına kayıtlı muhasebe meslek mensupları ile anket çalışması yapılmıştır.

\subsection{Araştırma Evreni}

Karaman SMMM odasına kayıtlı 206 adet mali müşavir bulunmaktadır (http://www.karamansmmmo.org.tr/uyelistesi.aspx, Erişim Tarihi: 12.02.2019). Bu mali müşavirlerin 10 adedi ilçelerde görev yapması, 5 adedi ise çeşitli nedenlerle mesleği bırakmış olmaları nedeniyle çalışma kapsamı dışında bırakılmıştır. Araştırma evrenini oluşturan ana kütle 191 adet mali müşavirden oluşmaktadır. 


\subsection{Araştırmanın Örneklemi}

Araştırmada ana kütle büyüklüğü biliniyor ise örneklem belirlemek için aşağıdaki formülden yararlanılır (https://www.cozumarastirma.com.tr/orneklem-belirleme/, Erişim Tarihi 12.02.2019).

$\mathrm{n}=\frac{N * t^{2} * p * q}{d^{2} *(N-1)+t^{2} * p * q}$

Buna göre,

$\mathrm{N}$ : Ana kütle büyüklüğü

$\mathrm{n}$ : Örneklem Büyüklüğ̈ü

p: İlgilenilen Olayın Görülme Olasılı̆̆1

q: $1-p$ (veya ilgilenilen olayın görülmeme olasıllı̆ı)

d: Kabul edilen +/- örnekleme hata oranı

t: anlamlılık düzeyini ifade etmektedir.

Formülden yararlanılarak ana kütleyi oluşturan 191 adet mali müşavirin, $t$ istenilen anlamlılık düzeyi \%5 $(\mathrm{t}$ tablosu değeri 1,96$)$ ve $\mathrm{d}$ kabul edilen $( \pm 5)$ örneklem hata oranı ile örneklem büyüklüğ̈̈ aşağıdaki gibi bulunmuştur.

$$
\mathrm{n}=\frac{191 *(1,96)^{2} * 0,50 * 0,50}{(0,05)^{2} *(191-1)+(1,96)^{2} * 0,50 * 0,50}=127,79
$$

$\% 5$ hata payı ile yapılacak olan çalışmada asgari anket sayısı 128 olarak bulunmuştur. Karaman da mali müşavirler ile 150 adet yapılmıştır. 12 adet anket eksik ve tutarsızlıkları nedeniyle çalışmaya dahil edilmemiştir. Çalışma geçerli kabul edilen 138 anket ile hazırlanmıştır.

\subsection{Araştırmanın Sınırılıkları}

Çalışma Karaman ili ile sınırlı tutulmuştur. Karamanda 206 adet mali müşavirden 5'i mesleği çeşitli nedenlerle yapmaması 10 adedi ise ilçelerde çalışıyor olması nedeniyle çalışmaya dahil edilmemiştir.

\section{6.Çalışmada Kullanılan Yöntem ve Teknik}

Muhasebe meslek mensupları, e-muhasebe uygulamalarının aktif kullanıcıları olmaları nedeniyle bu konuda yaşanan sorunları ortaya koyabilecek en uygun meslek gurubu olduğunu söylemek yanlış olmaz. Bu bağlamda çalışmada veri elde etmek amacıyla anket tekniğinden yararlanılmıştır. Anket verileri görevlendirilen anketörler aracıllğııla yüz yüze görüşme yapılarak doldurulmuştur. Anket toplama süreci 26.12.2018 tarihinde başlamış, 06.02.2019 tarihinde tamamlanmıştır. Çalışma için kullanılan anket formunun oluşturulmasında; Elçin ve diğ. (2018), Gönen ve Solak (2017), Çınar ve Güney (2012) tarafindan yapılan çalışmalardan ve Serbest Muhasebeci Mali Müşavirler ile yapılan mülakatlar sonucu edinilen bilgilerden yararlanılmıştır. Anket demografik bilgiler ve 5'li likert ölçeğine göre hazırlanmış sorulardan oluşmaktadır. Ölçekte sayısal değerler 1 Kesinlikle Katılmıyorum, 2 Katılmıyorum, 3 Ne Katılıyorum Ne Katılmıyorum, 4 Katılıyorum, 5 Kesinlikle Katılıyorum olarak belirlenmiştir. Anket verilerinin analizi için SPSS 25 paket programı kullanılmıştır. Ölçek güvenilirliği ise SPSS Cronbach's Alpha değerine göre belirlenmiştir.

Cronbach Alfa Katsayıs1 0-0,39 aras1 ölçeğin güvenilir olmadığ1, 0,40-0,59 arası düşük güvenilirliğin olduğu, 0,60-0,79 ölçeğin oldukça güvenilir olduğu, 0,80-1 aralığının ise yüksek derecede güvenilir bir ölçek olduğunu göstermektedir (Akgül ve Çevik, 2005:435-436).

\subsection{Araştırma Bulguları}

Muhasebede e-dönüşüm sürecinde yaşanan sorunların tespitine yönelik olarak muhasebe meslek mensuplarına yönelik yapılan anket çalışmasına ait bulgular Tablo 1'de verilmiştir. 
Tablo 1: Demografik Bilgiler

\begin{tabular}{|c|c|c|c|c|}
\hline \multicolumn{2}{|l|}{ Demografik Bilgiler } & \multirow{2}{*}{$\begin{array}{c}\text { Frekans } \\
119\end{array}$} & \multirow{2}{*}{$\begin{array}{c}\text { Oran }(\%) \\
86,2\end{array}$} & \multirow{2}{*}{$\begin{array}{c}\begin{array}{c}\text { Kümülatif } \\
\text { Oran (\%) }\end{array} \\
100,0\end{array}$} \\
\hline & Bay & & & \\
\hline CIIsтуе & Bayan & 19 & 13,8 & 13,8 \\
\hline \multirow{5}{*}{ Yaş } & 24 ve alt1 & 2 & 1,4 & 1,4 \\
\hline & $25-34$ & 19 & 13,8 & 15,2 \\
\hline & $35-44$ & 49 & 35,5 & 50,7 \\
\hline & $45-54$ & 56 & 40,6 & 91,3 \\
\hline & 55 ve üstü & 12 & 8,7 & 100,0 \\
\hline \multirow{4}{*}{ Eğitim Durumu } & Lise ve alt 1 & 6 & 4,3 & 4,3 \\
\hline & Önlisans & 12 & 8,7 & 13,0 \\
\hline & Lisans & 106 & 76,8 & 89,9 \\
\hline & Lisansüstü & 14 & 10,1 & 100,0 \\
\hline \multirow{5}{*}{ Mesleki Deneyim Süresi } & 5 y1l ve altı & 11 & 8,0 & 8,0 \\
\hline & $6-10$ y1l & 30 & 21,7 & 29,7 \\
\hline & $11-15$ y1l & 33 & 23,9 & 53,6 \\
\hline & $16-20 \mathrm{y} 1 \mathrm{l}$ & 27 & 19,6 & 73,2 \\
\hline & 21 y1l ve üzeri & 37 & 26,8 & 100,0 \\
\hline \multirow{2}{*}{ Çalışma Şekli } & Bağımlı & 23 & 16,7 & 16,7 \\
\hline & Bağımsız & 115 & 83,3 & 100,0 \\
\hline \multirow{3}{*}{ Mesleki Unvanı } & Muhasebe Personeli & 8 & 5,8 & 5,8 \\
\hline & Stajyer SMMM & 1 & 0,7 & 6,5 \\
\hline & SMMM & 129 & 93,5 & 100,0 \\
\hline
\end{tabular}

Tablo 1'den de anlaşılacağı üzere katılımcıların büyük bir çoğunluğu erkek meslek mensuplarından oluşmaktadır. Yaş gruplarına bakıldığında 35-54 yaşlar arasında yoğunluğun olduğu görülmektedir. Katılımcıların \%76,8'i gibi büyük bir oranı lisans mezuniyetine sahiptir. Mesleki deneyim süresi en yüksek $\% 26,8$ ile 21 y1l ve üzeri çalışanlar oluşturmaktadır. Ankete katılanların \%70,3'ü mesleki deneyim süresi bakımından 11 yıl ve üzeri tecrübeye sahip kişilerdir. Ankete cevap verenlerin \%93,5 SMMM'ken katılımcıların \%83,3’ü bağımsız olarak çalıştıklarını beyan etmişlerdir.

Muhasebe meslek mensuplarının e-dönüşüm ile ilgili vermiş oldukları bilgiler tablo 2'de gösterilmiştir. 
Tablo 2: E-Dönüşüm Soruları

\begin{tabular}{|c|c|c|c|c|}
\hline \multicolumn{2}{|l|}{ E-Dönüşüm Soruları } & \multirow{2}{*}{$\begin{array}{c}\text { Frekans } \\
113\end{array}$} & \multirow{2}{*}{$\begin{array}{c}\text { Oran }(\%) \\
81,9\end{array}$} & \multirow{2}{*}{$\begin{array}{c}\text { Kümülati } \\
\text { Oran (\%) } \\
81,9\end{array}$} \\
\hline & Zorunlu Olarak & & & \\
\hline E-Donuşume danil orma sureci? & Gönüllü Olarak & 25 & 18,1 & 100,0 \\
\hline \multirow{4}{*}{$\begin{array}{l}\text { E-Uygulamalardan yararlanan } \\
\text { mükellef sayınız? }\end{array}$} & $1-5$ & 50 & 36,2 & 36,2 \\
\hline & $6-10$ & 50 & 36,2 & 72,4 \\
\hline & $11-15$ & 14 & 10,1 & 82,5 \\
\hline & 16 ve üzeri & 24 & 17,5 & 100 \\
\hline \multirow{4}{*}{$\begin{array}{l}\text { Mükelleflerinizin } \\
\text { uygulamalardan yara } \\
\text { şekli? }\end{array}$} & GİB Portal ile & 73 & 52,9 & 52,9 \\
\hline & Özel Entegratör ile & 16 & 11,6 & 64,5 \\
\hline & Entegratör Aracilıyla & 9 & 6,5 & 71,0 \\
\hline & GİB Portal ve Özel Entegratör & 40 & 29,0 & 100,0 \\
\hline \multirow{3}{*}{ 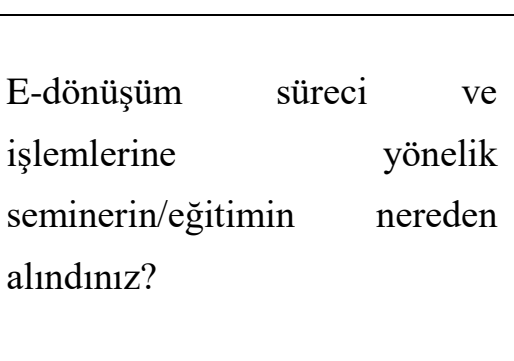 } & SMMM Odasindan & 121 & 87,7 & 87,7 \\
\hline & $\begin{array}{l}\text { Hazine ve Maliye } \\
\text { Bakanlığı'ndan }\end{array}$ & 2 & 1,4 & 89,1 \\
\hline & $\begin{array}{l}\text { Herhangi Bir Yerden Eğitim } \\
\text { Almadım }\end{array}$ & 15 & 10,9 & 100,0 \\
\hline \multirow{5}{*}{$\begin{array}{l}\text { E-dönüşüm } \\
\text { işlemlerine } \\
\text { seminer/eğitim } \\
\text { durumunuz? }\end{array}$} & Hiç Katılmadım & 15 & 10,8 & 10,8 \\
\hline & $1-3$ & 69 & 50,0 & 60,8 \\
\hline & $4-7$ & 33 & 23,9 & 84,7 \\
\hline & $8-11$ & 11 & 8,0 & 92,7 \\
\hline & 12 ve üstü & 10 & 7,3 & 100,0 \\
\hline \multirow{5}{*}{$\begin{array}{l}\text { E-dönüşüm } \quad \text { süreci } \quad \text { ve } \\
\text { işlemlerinde } \\
\text { sıklığın nedir? }\end{array}$} & $1-5$ & 82 & 59,4 & 59,4 \\
\hline & $6-11$ & 35 & 25,4 & 84,8 \\
\hline & $12-17$ & 6 & 4,3 & 89,1 \\
\hline & $18-23$ & 8 & 5,8 & 94,9 \\
\hline & 24 ve üzeri & 7 & 5,1 & 100,0 \\
\hline
\end{tabular}

Tablo 2'de görüldüğü üzere muhasebe meslek mensuplarının \%81,9'u e-muhasebe uygulamalarını zorunlu olarak kullanmaya başladıklarını gönüllü kullanmaya başlayanların oranının ise \%18,1'de kaldığı görülmektedir. Katılımcıların \%52,9'u e uygulamaları kullanmak için GİB portalını kullandığı E uygulamaları kullanan mükellef sayılarının ise \%72,4 ile 1-10 kişi arasında olduğu gözlemlenmiştir. E-muhasebe süreci ve 
işlemlerine yönelik olarak seminer veya eğitimlerin \%87,7'sini Karaman SMMM Odasından aldıklarını söylerken bu sistemleri kullanmalarına rağmen \%10,9'luk bir kesimin hiçbir eğitim almadığı anlaşılmaktadır. E-dönüşüm süreci ve işlemlerinde sorun yaşanma sıklığı \%84,8 ile 1-11 arasında gerçekleşmiştir.

5'li likert ölçeğine göre hazırlanan anket 3 kısımdan oluşmaktadır. İfadelerin güvenilirliğini belirlemek için SPSS Cronbach's Alpha değeri her bir kısımda ayrı ayrı hesaplanmıştır.

E-dönüşümün muhasebe meslek mensuplarının iş yükü ve performansına yönelik sorunların tespiti için oluşturulan ifadelerin SPSS Cronbach's Alpha değeri 0,821 olarak bulunmuştur. Bu değere göre ölçeğin yüksek derecede güvenilir olduğu söylenebilir. E-dönüşümün muhasebe meslek mensuplarının iş yükü ve performansına yönelik ifadelere verilen cevapların ortalamaları Tablo3'de gösterilmiştir.

\section{Tablo 3: İș Yükü ve Performans}

\begin{tabular}{|l|c|c|c|}
\hline \multicolumn{1}{|c|}{ İş Yükü ve Performans } & $\begin{array}{c}\text { Cevap } \\
\text { Sayısı }\end{array}$ & Ortalama & $\begin{array}{c}\text { Standart } \\
\text { Sapma }\end{array}$ \\
\hline $\begin{array}{l}\text { E-fatura ve E-defter kullanımında düzeltilmeyecek hata yapma } \\
\text { ihtimali iş performansını olumsuz etkiliyor. }\end{array}$ & 138 & 3,83 & 1,120 \\
\hline $\begin{array}{l}\text { E-fatura ve E-defter kullanımında kayıtlı bilgilerin silinebilmesi } \\
\text { ihtimali iş performansını olumsuz etkiliyor. }\end{array}$ & 138 & 3,74 & 1,161 \\
\hline $\begin{array}{l}\text { E-defter uygulamasında bir defterin boyutunun sınırlandırılması } \\
\text { sonucunda sınırı aşan defterin bölünmesi bazı teknik ve kullanım } \\
\text { hatalarına yol açar ve muhasebenin iş yükünü artırır. }\end{array}$ & 138 & 3,91 & 1,070 \\
\hline $\begin{array}{l}\text { E-defter kayıtlarında her belgenin tek bir yevmiye kaydında } \\
\text { muhasebeleştirilmesi muhasebenin iş yükünü artırır. }\end{array}$ & 138 & 3,72 & 1,225 \\
\hline $\begin{array}{l}\text { E-defter içerik bilgilerinin sistemde bulunmaması-defterin sisteme } \\
\text { yüklenmesi sırasında bazı hataların yapılmasına yol açar. }\end{array}$ & 138 & 3,77 & 1,135 \\
\hline $\begin{array}{l}\text { E-defter uygulamasında işlem yapılan her aya ilişkin beratın alınması } \\
\text { zorunluluğu muhasebenin iş yükünü artırır. }\end{array}$ & 138 & 3,91 & 1,057 \\
\hline $\begin{array}{l}\text { E-Muhasebe uygulamaları muhasebe meslek mensuplarının iş } \\
\text { yükünü arttırmıştır. }\end{array}$ & 138 & 4,03 & 1,114 \\
\hline Oralama & $\mathbf{1 3 8}$ & \\
\hline
\end{tabular}

Tablo 3'de de görüldüğ̈̈ üzere e-dönüşümün muhasebe meslek mensuplarının iş yükü ve performansa etkisinin ortalamas1 3,84 (4 Katılıyorum'a daha yakın) seviyesinde olduğu görülmektedir. E-uygulamalarda kayıtlı bilgilerin silinmesi ve hata yapma ihtimalinin muhasebe meslek mensuplarının iş performansını olumsuz etkilediğini belirtilmiştir. E-muhasebe uygulamaları muhasebe meslek mensuplarının iş yükünü arttırdığı düşüncesi 4,03 (4 Katılıyorum) ortalama ile iş yükü ve performansa ilişkin ölçeklerden sorun olarak görülen en yüksek değer olmuştur. Meslek mensupların iş yükü arttıran, e-defter boyutunun sınırlandırılması sonucu oluşan hatalar, her bir belgeyi tek bir yevmiye kaydında muhasebeleştirilmesi, her aya ilişkin işlem beratının alınması gibi durumlar 3,84 ile ortalamanın üzerinde (4 Katılıyorum'a daha yakın) bir oranda birer sorun olarak görülmektedir.

E-dönüşüm konusunda alt yapıya yönelik sorunların tespitine yönelik oluşturulan ifadeler için SPSS Cronbach's Alpha değeri 0,637 olarak bulunmuştur. Buna göre ölçek oldukça güvenilirdir. E-dönüşüm konusunda muhasebe meslek mensuplarının personel ve maliyetlerine yönelik sorulara verilen cevapların ortalamaları Tablo4'de gösterilmiştir. 
Tablo 4: Alt Yapı

\begin{tabular}{|l|c|c|c|}
\hline \multicolumn{1}{|c|}{ Alt Yapı } & $\begin{array}{c}\text { Cevap } \\
\text { Sayısı }\end{array}$ & Ortalama & $\begin{array}{c}\text { Standart } \\
\text { Sapma }\end{array}$ \\
\hline $\begin{array}{l}\text { Kullanmakta olduğunuz muhasebe programı e-dönüşüm için } \\
\text { yeterli alt yapıya sahiptir. }\end{array}$ & 138 & 3,91 & 1,017 \\
\hline $\begin{array}{l}\text { Mevzuat değişiklikleri bilişim sistemine zamanında } \\
\text { uyarlanmamaktadır. }\end{array}$ & 138 & 3,82 & 1,160 \\
\hline $\begin{array}{l}\text { Elektronik ortamda Gelir İdaresi Başkanlığı'na erişimde zaman } \\
\text { zaman sıkıntıların yaşanmaktadır. }\end{array}$ & 138 & 3,83 & 1,085 \\
\hline $\begin{array}{l}\text { Erişimdeki aksaklıklardan dolayı beyannameler zamanında } \\
\text { verilmediğinde, bunun idare tarafından mücbir sebep olarak kabul } \\
\text { edilmemektedir. }\end{array}$ & 138 & 3,60 & 1,193 \\
\hline $\begin{array}{l}\text { E-fatura ve E-defter kullanımında sürekli teknik problemler } \\
\text { yaşanmaktadır. }\end{array}$ & 138 & 3,57 & 1,171 \\
\hline \multicolumn{1}{|c|}{ Ortalama } & $\mathbf{1 3 8}$ & $\mathbf{3 , 7 5}$ & \\
\hline
\end{tabular}

Muhasebede e-dönüşümün konusunda yaşanan alt yap1 sorunlarına ilișkin ifadelere verilen cevapların ortalamas 3,75 ile (4 Katılıyorum'a daha yakın) olduğu belirlenmiştir. 3,91 ortalama ile kullanılmakta olan muhasebe programlarının e-dönüşümünde herhangi bit alt yapı sorunun olmadığı anlaşılmaktadır. Ancak mevzuat değişikliklerinin zamanında uyarlanmaması, GïB portala erişimde aksaklıklar yaşanması alt yapı sorunu olarak görülen konular olmuştur.

E-dönüşümün konusunda maliyet ve eleman eksikliğine ilişkin ifadeler için SPSS Cronbach's Alpha değeri 0,608 olarak bulunmuştur. Buna göre Cronbach's Alpha değeri literatürde kabul edilen sinırın üzerinde olmas1 nedeniyle ölçek oldukça güvenilir olarak nitelendirilebilir. E-dönüşümde eğitim ve eleman eksikliği konusunda sorunlara ilişskin ifadelere verilen cevaplar Tablo 5'de gösterilmiştir.

Tablo 5: Maliyetler ve Eleman Eksikliği

\begin{tabular}{|c|c|c|c|}
\hline Maliyetler ve Eleman Eksikliği & Cevap Sayısı & Ortalama & $\begin{array}{c}\text { Standart } \\
\text { Sapma }\end{array}$ \\
\hline $\begin{array}{l}\text { E-muhasebe sistemine geçen işletmelerde kalifiye eleman eksikliği önemli bir } \\
\text { sorundur. }\end{array}$ & 138 & 4,20 & 0,870 \\
\hline E-muhasebe uygulamaları konusunda mükellefler yeterli bilgilendirilmemektedir. & 138 & 3,76 & 1,235 \\
\hline Meslek mensupları, muhasebe yazılımlarını yeterli düzeyde bilmemektedir. & 138 & 3,25 & 1,289 \\
\hline E-dönüşümün hizmet maliyetini artırmaktadır. & 138 & 3,95 & 1,180 \\
\hline E-dönüşüm mükelleflerime ek maliyet getirmektedir. & 138 & 3,86 & 1,135 \\
\hline E-dönüşüm için muhasebe yazılımları pahalıdır. & 138 & 4,04 & 1,130 \\
\hline $\begin{array}{l}\text { E-fatura ve E-defterin kullanımı hakkında GİB tarafindan yapılan bilgilendirme } \\
\text { yeterlidir. }\end{array}$ & 138 & 3,22 & 1,307 \\
\hline Ortalama & 138 & 3,75 & \\
\hline
\end{tabular}


Tablo 5'den de anlaş1lacağı üzere e-dönüşümde eğitim ve eleman eksikliği konusunda sorunlara ilişkin ifadelere verilen cevapların ortalaması 3,75 ile (4 Katılıyorum'a daha yakın) olduğu belirlenmiştir. En çok algılanan sorun ise 4,20 ortalama ile kalifiye eleman eksikliği görülmektedir. Aynı şekilde mükelleflerinde edönüşüm konusunda bilgilendirilmesi gerektiği belirtilmiştir. E- dönüşüm için muhasebe yazılımlarının pahalı olması, ek maliyet getirmesi ve hizmet maliyetini arttırması algılanan diğer sorunlar olmuştur.

\section{SONUÇ}

Teknolojide yaşanan gelişmeler hayatın her alanında etkili olduğu gibi muhasebe alanda da kendini göstermiş ve rasyonel değişimlere neden olmuştur. Muhasebe alanında bilgisayar yazılımlarının kullanılmasıyla başlayan teknolojik değişim ve dönüşümler günümüzde mali işlemlerin bir çoğunun elektronik ortamda hazırlanmasına imkan verebilecek düzeye gelmiştir. Bugün e-uygulamalar olarak da nitelendirilebilen e-fatura, e-defter, e-arşiv gibi uygulamalar bilgi teknolojilerinin getirdiği en son yeniliklerdir.

Muhasebede e-dönüşümü sağlayabilmek için Hazine ve Maliye Bakanlığg yetkilendirilmiş ve ilk olarak belli şartlar altında e-fatura kullanımını zorunlu hale getirerek e-dönüşüm süreci başlatmıştır. Sonraki süreçte e-fatura uygulamasının kapsamının genişletilmesi ve diğer e-uygulamaların kullanımın sağlanması ile edönüşüm süreci hızlandırılmıştır.

Kayıt dışı ekonomiyi tespit edebilmek, vergi kaçağını önleyerek vergi gelirlerinin arttırılmasını sağlayabilmek, mükelleflerin denetiminin çok daha hızlı ve kaliteli olarak yapılabilmesini olanak sağlamak, bilgiye erişim hızını arttırabilmek, işletme maliyetlerinde tasarruf sağlayabilmek, belgelerin muhafazasını kolaylaştırabilmek gibi amaçlar nedeniyle muhasebenin e-dönüşüm süreci başlamıştır.

Her ne kadar e-dönüşümünün sağlayabileceği avantajlar bulunsa da uygulamada çeşitli sorunların da yaşanabileceğini söylemek yanlış olmaz. Bu nedenle çalışmada, e-uygulamaların en aktif kullanıcıları olan muhasebe meslek mensuplarının e-dönüşüm sürecinde yaşadıkları sorunların tespit edilerek çözüm önerilerinin getirilmesi amaçlanmıştır. Çalışma evrenini oluşturan Karaman Serbest Muhasebeci Mali Müşavirler Odasına kayıtlı 206 adet muhasebe meslek mensubu bulunmaktadır.

Yapılan çalışama ile e-dönüşüme zorunlu olarak dahil olanların ve e-uygulamalara GỉB portal üzerinden ulaşanların oranının çok daha fazla olduğu, e-uygulamalar konusunda eğitim ve seminerlerin ise çoğunlukla Karaman Serbest Muhasebeci Mali Müşavirler Odası'ndan aldıkları anlaşılmıştır. \%10,8 gibi bir oranda meslek elemanının e-dönüşüm konusunda herhangi bir eğitim almadıklarını söylemesi ise dikkat çekici bir orandir.

E-dönüşüm uygulamaları muhasebe meslek mensuplarının iş yükünü arttırdığı, hata yapma ihtimalinin ise iş performansını olumsuz etkilediği anlaşılmıştır. Mevzuat değişikliklerinin zamanında uyarlanamaması, GİB portala erişimde aksaklıklar yaşanması alt yapı sorunu olarak görülen diğer konular olmuştur.

E-dönüşümün getireceği maliyetler ve nitelikli eleman eksikliğine ilişkin sorunların tespitine yönelik oluşturulan ifadeler de en büyük sorun algısının kalifiyeli eleman eksikliği olduğu anlaşılmıştır. E-dönüşüm konusunda mükelleflere de eğitimler verilmesi gerektiği, muhasebe yazılımlarının pahalı olması ve ek maliyetler getirmesi sorun olarak görülen başka konu başlıkları olmuştur.

Sonuç olarak, en çok sorun olarak algılanan konu kalifiyeli eleman ve e-uygulamalar konusunda verilen eğitimlerin eksikliği olmuştur. Zira e-uygulamaları kullanmasına rağmen hiçbir eğitim almadığını beyan eden $\% 10,8$ gibi bir oran bulunmaktadır. Aynı zamanda e-uygulamaları kapsamının genişletilerek kullanan mükellef sayısı ilerleyen yıllarda artacağı öngörüldüğü için nitelikli eleman ihtiyacı da artacaktır. Bu eksikliğin giderilmesi için başta Hazine ve Maliye Bakanlığı ve muhasebe meslek odaları olmak üzere e-uygulamalar konusunda verilen eğitimleri periyodik olarak tekrarlamalıdırlar. Üniversitelerin, muhasebe e-uygulamaları konusunda verecekleri eğitimler ile piyasanın ihtiyacı olan nitelikli elemanın yetiştirilmesine katk1 sağlanabilecektir. Düzenlenen eğitim, seminer ve panellere sadece Serbest Muhasebeci Mali Müşavirler değil e-uygulamaları gönüllü veya zorunlu olarak kullanan mükelleflerinde faydalanmasını sağlamak yararlı olacaktır. Bu eğitim hizmetlerine erişimin kolaylaştırılabilmesi için online eğitim portalları geliştirilmesi sürece katkı sağlayacaktır.

E-dönüşüm teknolojik alt yapı gerektiren uygulamalar olması nedeniyle işletmelere ek maliyetler getirebilmektedir. Bu alt yapı eksikliğinin giderilebilmesi ve mükelleflerin gönüllü olarak da sisteme katılımının arttırılabilmesi için devletin e-uygulama kullanıcılarına ekonomik teşvik sağlaması yararlı olacaktır. Bu sayede e-uygulamaları kullanan mükellef sayısı attırılarak beklenen katma değer sağlanmış olacaktır. Verilecek ekonomik teşvikler vergi kaybını önlenmesine dolayısıyla vergi gelirlerinin arttırılmasına fayda sağlayacaktır. 
Meslek mensuplarının iş yükü ve performansına yönelik sorunların çözümü için kullanılan uygulamaların basitleştirilmesi, sistem eksikliklerinin giderilmesi, yapılabilecek hataların zamanında düzeltilebilmesi kısmen de olsa faydali olacaktır. 


\section{KAYNAKÇA}

Akgül, A., ve Çevik, O. (2005). İstatistiksel Analiz Teknikleri "SPSS'te İşletme Yönetimi Uygulamaları" (2. Baskı). Ankara: Emek Ofset.

Amudi, M., Effah, J., ve Abor, J. (2011). E-Accounting Practices Among Small and Medium Enterprises İn Ghana. Journal of Management Policy and Practice, 12(4), 146-155.

Calayoğlu, İ. (2019). Elektronik Vergi Denetimindeki Teknolojik Gelişmeler ve Tam Denetime Geçiş Adımları. Muhasebe ve Finansman Dergisi, (81), 143-162.

Çınar, O., ve Güney, S. (2012). Muhasebe Meslek Mensuplarının E-Sorunlar Hakkındaki Görüşleri: Erzurum Örneği. Ekev Akademi Dergisi, (50), 259-272.

Çözüm Araştırma Eğitim ve Danışmanlık Sitesi, https://www.cozumarastirma.com.tr/orneklem-belirleme/, [ İndirme Tarihi 12.02.2019].

Demirkan, B. (2013). Son Düzenlemeler Işığında Elektronik Fatura Uygulaması. Vergi Raporu Dergisi, (166), 68-73.

Dinç, E., ve Karakaya, A. (2004). Muhasebe Meslek Elemanlarının Genel Özelliklerinin E- Muhasebe Uygulamaları Üzerine Etkileri: Doğu Karadeniz Bölgesi Örneği. Karamanoğlu Mehmetbey Üniversitesi İktisadi ve İdari Bilimler Fakültesi Dergisi EA Selçuk Üniversitesi Karaman İktisadi ve İdari Bilimler Fakültesi Dergisi, (4), 119-134.

Doğan, U., ve Tercan, Y. (2015). e-Defter İle Neler Değişti, Neler Değişecek, https://www.tayyarates.com.tr/singlepost/2015/04/01/eDefter-\%C4\%B0le-Neler-De\%C4\%9Fi\%C5\%9Fti-Neler-De\%C4\%9Fi\%C5\%9Fecek, [İndirme Tarihi: 30.01.2019].

E-Defter Genel Teliği. (Sıra No 1); 13.12 .2011 tarih ve 28141 Sayılı Resmi Gazete.

Elçin, R., Gerekan, B., ve Usta, M. (2018). E-Fatura, E-Defter, ve E-Arşiv Uygulamalarına Geçiş Sürecinde Yaşanan Sorunlar: Serbest Muhasebeci Mali Müşavirler Üzerine Bir Araştırma. Mali Çözüm, (146), 13-42.

Gelir İdaresi Başkanlığı E-Defter Sitesi: http://www.edefter.gov.tr/edefterkayitlikullanicilar.html, [İndirme Tarihi: 03.02.2019].

Gelir İdaresi Başkanlığı E-Fatura Sitesi: http://www.efatura.gov.tr/efaturahakkinda.html, [İndirme Tarihi: 02.01.2019].

Gökçen, G., ve Özdemir, M. (2016). Türkiye'de Muhasebe Uygulamalarından E-Defter ve E-Fatura Uygulaması. Marmara Üniversitesi Öneri Dergisi, 12(46), 137-154.

Gönen, S., ve Solak, B. (2017). Maliye Bakanlığı E-Dönüşüm Sürecinin Muhasebe Meslek Mensupları Açısından Değerlendirilmesine İlişkin Bir Alan Araştırması. Muhasebe ve Finansman Dergisi, (76), 63-80.

Güney, A. (2014). Role Of Tecnology İn Accounting and E-Accounting . Procedia - Social and Behavioral Sciences, (152), 852-855.

Güney, S., ve Özyiğit, H. (2015). Muhasebedeki Verileri Yönetiminde Kullanılması ve Elektronik Muhasebe Verilerinin Yönetim Kararlarına Etkisi. Elektronik Sosyal Bilimler Dergisi, 14(53), 279-297.

İstanbul Yeminli Mali Müşavirler Odası, http://www.istanbulymmo.org.tr/Data/Platform/823.pdf, [İndirme Tarihi: 12.02.2019].

Kara, M., ve Yılmaz, A. B. (2017). Serbest Muhasebeci ve Mali Müşavirlerde E-Belge Kullanımı ve Uygulamaları. Yüzüncü Y1l Üniversitesi Sosyal Bilimler Enstitüsü Dergisi, (35), 253-268.

Karaman Serbest Muhasebeci Mali Müşavirler Odas1, http://www.karamansmmmo.org.tr/uyelistesi.aspx, [İndirme Tarihi:12.02.2019].

Karasioğlu, F., ve Samancı, T. H. (2018). Mali Müşavir-Mükellef İlişkileri Bağlamında Beklentiler, Sorumluluklar ve Yükümlüükler; Karaman İli Özelinde Bir Anket Çalışması. Akademik Sosyal Araştırmalar Dergisi, (67), 432-451.

Lian, J. W. (2015). Critical Factors for Cloud Based E-İnvoice Service Adoption in Taiwan:An Empirical Study. International Journal of Information Management, 98-109.

Marinagi, C., Trivellas, P., Reklitis, P., ve Skourlas, C. (2015). Adoption and Use of E-invoicing in Greece. International Conference on Integrated Information, 279-286.

Ortega, B. H. (2012). Key Factors for the Adoption and Subsequent use of E-Invoicing. Academia Revista Latinoamericana de Administracion, 15-30.

Öz, E., ve Bozdoğan, D. (2012). Türk Vergi Sisteminde E- Maliye Uygulamları. Süleyman Demirel Üniversitesi İktisadi ve İdari Bilimler Fakültesi Dergisi, 17(2), 67-92.

Spoz, A. (2014). A Look At E- Invoices From Enterprises And Government's Perspective. Research Papers of Wroclaw University of Economics, 254-264.

Tektüfekçi, F. (2017). E-Dönüşüm Sürecinde E- Muhasebe Uygulamaları: Türkiye Örneği. Bilgi Ekonomisi ve Yönetimi Dergisi, 12(1), 79-88.

Tektüfekçi, F. Ş. (2013). Bilişim Teknolojilerindeki Gelişmelerin Muhasebe Uygulamalarına Etkisi: E- Muhasebe. Sosyal ve Beşeri Bilimler Dergisi, 5(2), 89-102.

Vegi Usul Kanunu Genel Tebliği. (Sıra No 421); 14.12.2012 tarih ve 28497 Sayılı Resmi Gazete.

Vergi Usul Kanunu Genel Tebliği. (Sıra No 454); 20.06.2015 tarih ve 29392 Sayılı Resmi Gazete.

Yanık, R., ve Karadaş, A. (2013). E-Faturanın Türkiye Muhasebe Standartları Uyum Sürecine Uygun Düzenlenmesine İlişkin Bir Öneri. Ekev Akademi Dergisi, 133-141.

Yürekli, E., Gönen, S., ve Şahiner, A. (2016). E-Fatura Uygulamasına İlişkin Bir Değerlendirme. Akademik Sosyal Araştırmalar Dergisi, (35), 290-302. 